\title{
The sacred second: religious moments in a Colombo marketplace
}

\author{
Alexander McKinley \\ Religious Studies Department, Duke University, Durham, NC, USA
}

\begin{abstract}
How does the marketplace of a busy city shape the religious practices of its shopkeepers? Combining historical and ethnographic research, this article examines the cosmopolitan past and present of Colombo's Pettah neighbourhood. Its role as an Indian Ocean port resulted in a continual influx of new religious players, leaving its present pluralistic pantheon, from which shopkeepers (many of whom have made their own transoceanic journeys to work in other port cities like Dubai) can choose the saint or god best suited for their needs. Meanwhile, the pace of the marketplace has structured religious time accordingly; sacred moments are improvised sporadically among the bustle of the business day. Religious ritual is now part of the general pattern of marketplace routine, along with a number of other habits for passing time - unscheduled but expected activity, both personally meaningful and socially symbolic. In turn, religious performance can enhance market performance, instrumentalised in spur-of-the-moment sales techniques, lines between sacred and profane continually blurred.
\end{abstract}

KEYWORDS Religion and marketplaces; sacred time; urban shrines; South Asia

Indeed, some crucial aspects of religious institutions make sense only if we understand what the market for religious services is like, what kind of commodity religious knowledge and ritual constitute. (Boyer 2001)

This article is about sacred time. In the mind of a postmodern student of religious studies a number of red flags should immediately raise. Though once the most en vogue concept of the discipline, famously wielded by landmark scholars such as Emile Durkheim and Mircea Eliade, the concept of the sacred has since been thoroughly deconstructed and marginalised by successive generations. Scholars in the vein of Durkheim and Eliade took the term to have a sui generis ontological quality, believing that 'the sacred' was a real metaphysical force in the world, tangible and definable only in contradistinction to the profane (Eliade 1959; Durkheim 1995). Later styles of scholarship, as in the work of Russell McCutcheon, levelled critiques against this language of the sacred on the

30 grounds that such phenomenological categories lacked explanatory value, as 
they were reliant only on subjective anecdotal evidence and inductive reasoning (2001). Yet the terminology of the sacred has also been rehabilitated by scholars like Ronald Grimes, who casts its meaning in more practical terms of how a particular object, space, or time is used. 'Sacrality becomes evident in how people act' $(2006,108)$. It is this meaning of the sacred as use that informs the present paper, which argues for an additional category of sacred time beyond the usual suspects like cyclic rebirth time or ritual time. This is the more immediate time of religion lived amidst the hectic. These are religious actions that cannot begin and end at precisely defined moments, a category I am calling the sacred second, explained here via religious practices in the Pettah market of Colombo. This is therefore also an article about time in the Pettah - the neighbourhood's past and present as a cosmopolitan space, and the manner in which sacrality there comes in stops and starts, affected by the demands of the modern marketplace.

Dhanuka arrived at his stall later than most, usually around ten in the morning. By ten o'clock the full bustle of the Pettah had already bloomed and would remain at a constant din until the sun fell in the evening. By ten o'clock Dhanuka's neighbour Sunil had already been working in his shop for two hours, along with his assistant salesmen Patrick and Zaruk. Sunil would also stay a couple hours later than Dhanuka, thus capitalising on both the early birds as well as the final straggling shoppers coming home from a late night at the office. This business strategy had earned Sunil a respectable fortune over the years, reflected in his car, home, and privately educated children. Dhanuka was a younger man with

25 a smaller shop, who traded additional business for time with his young son. He looked up to Sunil as a model for future success (Figure 1).

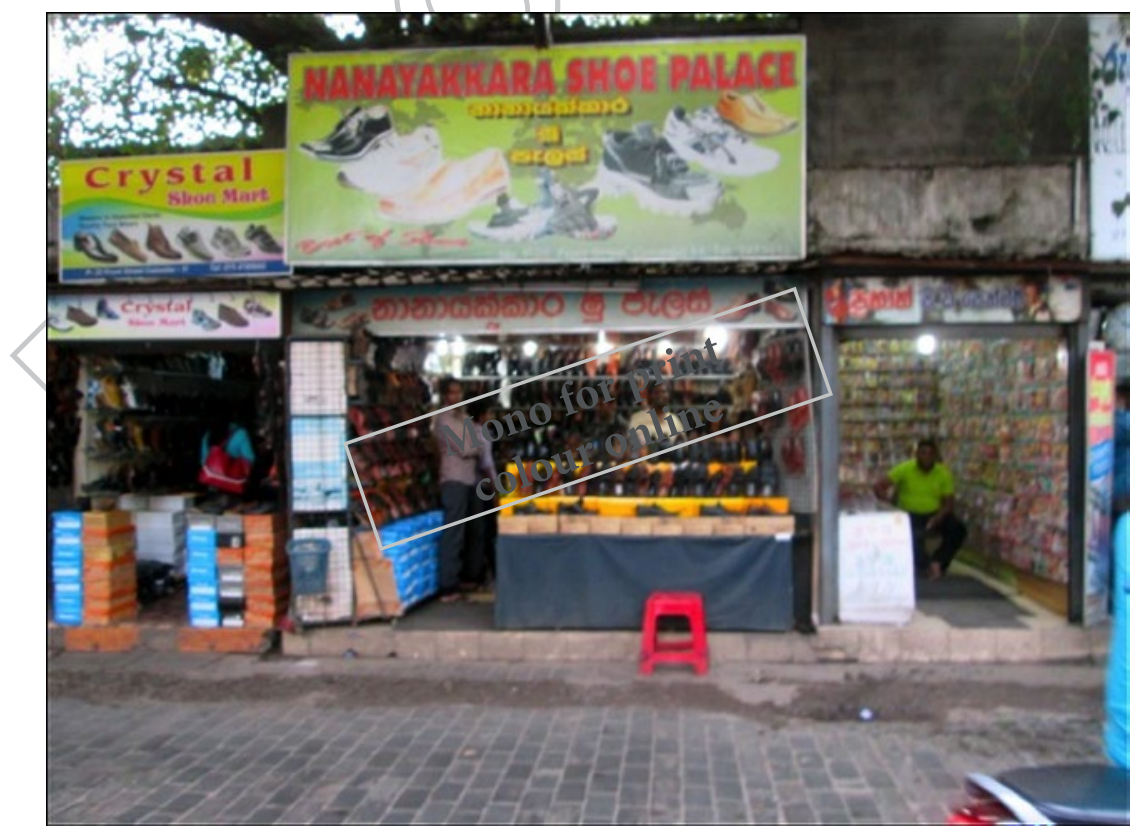

Figure 1. Dhanuka's 'Crystal Shoe Mart' and Sunil's 'Nanayakkara Shoe Palace.' Source: Photo by author. 
These four men comprised only a miniscule portion of the overall business that took place in the Pettah everyday during my time there in the summer of 2013 and many subsequent visits over the next three years. Situated on the edge of the neighbourhood, bordering the canal separating the Pettah from the more upscale Colombo Fort neighbourhood housing the skyscrapers of international commerce, the small stalls run by Dhanuka, Sunil, Patrick, and Zaruk were dwarfed by the their surroundings, easy to miss within the overall hecticity of the Pettah. Along the whole length of this long block stands one

10 shop after another, most only the size of a small storage locker with a pull-down door, though some have the equivalent of two such spaces. The shops make an unbroken row, essentially forming a wall that bounds the neighbourhood. It is mostly a street for shoes, though there are a few watch sellers and repairers, along with a pirate DVD shop or two. The street is narrow and paved with brick.

15 Despite these dimensions and the fact that it is usually filled with shoppers, it remains a functioning street, which means traffic continually forces its way through, kicking up clouds of grit that the shopkeepers must constantly dust off their wares. On the other side is a parking area, filled to the brim on every day of the week but Sunday - packed with cars, trishaws, and motorbikes. The

20 side streets on this half of the road lead into the heart of the Pettah - arteries usually clogged with old men selling old shoes, and old men pushing heavy carts. Within all this motion, the habits of the four in this paper act as a representative slice of life in the marketplace - its exchanges and exigencies, its relationships and religiosity. Through them one may catch a glimpse of how the

25 demands of the market force religion to tick by in interrupted second between interrupted second.

Market trends - polis \& cosmos

The Englishterminology of'the Pettah' was adapted from the Tamil pettai, meaning 'outside the fort' (Perera 1998, 48). In Sinhala the translation of the neigh-

30 bourhood name (pita koțuwa) is the same. This etymological connection to the Colombo Fort demonstrates the extent to which the Pettah is tied to successive colonial projects. Even before the colonial Pettah, however, Colombo was an important trade centre in the heyday of Muslim commerce on the Indian Ocean. Ibn Battúta described the port in 1344 as 'one of the finest and largest towns

35 in Ceylon. In it resides the wazír and ruler of the sea Jálasti, who has with him about five hundred Abyssinians' $(1929,260)$. Fourteenth century Colombo was something of a city-state, equipped with a small diasporic army, operating relatively autonomously from the Sinhala and Tamil royal capitals located farther north and inland during this period. Jálasti of Colombo was building a port

40 of his own order, a source of complaint for other global travellers, such as the Chinese sailor Wang Dayuan, who warned after visiting the city in the 1330 s that 
sailors who have had the misfortune to be wrecked, and who have to stop for a while in this place, are fleeced by the ruler of whatever merchandise their junk might have on board, even the gold and jewels are sent to him. He looks upon them as sent by Heaven, and little he knows and cares that they were expected by the sailors' wives and children to save them from starvation and cold. (Rockhill 1915, 384-5)

Jálasti's order was thus a divine one (however unjust in the eyes of the taxed) - a pairing of mercantile and religious aspirations that continues through the present.

The wealth of oceanic trade networks drew Sinhala royal capitals ever closer to the shore, until one settled just south of Colombo in the fifteenth century, which came to stand as a high point in Sinhalese literature and religious patronage. One of the decorated poet monks who composed a sandeśa poem describing a journey north from the capital did not fail to mention Colombo, expressing a vision of its commerce with religious imagery:

In the great divine river where celestial maidens play games,

Siddhas and Vidyadharas climbing atop dark clouds; likewise from huge Colombo, Wattala, and Putturu,

see the traders coming and going by boats and canoes. ${ }^{1}$

At the start of the sixteenth century, the location of Colombo was likely chosen as a main fort by the Portuguese due to its proximity to this capital of Kōtte, with which the Portuguese were in extended diplomatic negotiation (Strathern 2007; Biedermann 2014). By the seventeenth century, outpost had grown into polis; Friar Paulo da Trinidade wrote:

Nowadays, besides the fortress, we have here in Colombo a city ... one of the best and biggest in India ... The houses are all beautiful and new, as are also the streets ... protected by walls and splendid bastions which the city itself had ordered built at own costs. $(1972,28-9)$

Expenses quickly met due to the fact that 'many vessels touch this city. They come from other parts, bring salt and clothing and take away cinnamon, betel-nut and other merchandise of the country' $(1972,29)$. Ships also brought missionaries like the good friar and his proselytising zeal, continuing to link commerce with religion, and leaving a legacy that fills the current Pettah with friends of mine like Sudesh Fernando, of mixed name and religious background, who sports a gold crucifix in show of business acumen, and feels comfortable in either temple or church setting because mom was a Buddhist. Though he looks no different from his companions with Sinhala last names, Sudesh knows his roots. 'We are the original whites in Sri Lanka,' he teased me.

Thus from its beginnings, the Pettah constituted a cosmopolitan space, filled with a mix of native workers, foreign merchants and mercenaries, as well as European soldiers, missionaries and families. Sea trade ensured a steady influx of outsiders. Colombo fell to the Dutch and then to the British, who relished describing the Pettah as a mix of colours and sounds - a global cultural patois. Not to mention the linguistic patois; in 1820, six fanams could buy a guidebook 
for deciphering what the missionary press called 'Ceylon Portuguese' (Callaway 1820). Robert Percival was one of the first British officers to record the cosmopolis of the market during his travels about the island at the close of the eighteenth century. Percival admits the Pettah is 'called ... by us the black town, from its being chiefly inhabited by black merchants and tradespeople' (1805, 133). The negative connotation of 'blackness' and the Pettah went well beyond race as well. Its crowded dwellings were considered a public health hazard due to disease and drugs (1893, Castellani and Philip 1914; Philip and Hirst 1917). Meanwhile, the seedy underbelly of the neighbourhood became a trope in colonial travel literature and postcolonial novels alike (Gibson 1922; Muller 1995). Yet the description of Percival reveals the diversity went a great deal deeper than the racist moniker black town suggests:

There is no part of the world where so many different languages are spoken, or which contains such a mixture of nations, manners, and religions. Besides Europeans, and Cinglese, the proper natives of the island, you meet, scattered over every town, almost every race of Asiatics; Moors of every class, Malabars, Travancorians, Malays, Hindoos, Gentoos, Chinese, Persians, Arabians, Turks, Maldivians, Javians, and natives of all the Asiatic isles; Persees, or worshippers of fire ... There are also a number of Africans, Cafrees, Buganese a mixed race of Africans and Asiatics; besides the half-casts, people of colour, and other races which proceed from a mixture of the original ones. $(1805,136)$

Here Percival paints a picture of plurality, a hallmark of any port city, and an aspect of life in the Pettah that continues into the present day, although in somewhat simplified patterns.

British control of Colombo initially increased the cosmopolitan nature of the Pettah through the constant influx of dockworkers, and the use of the Euro-Asiatic Burgher population as intermediaries to help govern the island (Gooneratne 1966; Dharmasena 1985). The cultural diversity of the Pettah was a strong tourist draw for the British, mentioned in travelogues and advertisements, although the bustling and blending of the neighbourhood could also yield its fair share of problems for the colonial regime, supposedly 'hybrid' objects being so disruptive of the modern illusion of exercising control via orderly boundaries (Latour 1993). Incidents in the Pettah were the frequent topics of police reports, and colonial officials were especially wary of subversive political demonstrations stirring public sentiments in the streets (1849, $151,156-7)$. This was for good reason as the Pettah became a locus of political activity with new Ceylonese political and mercantile elite, a mix of Burgher and native, capable of starting revivalist movements and challenging British (Roberts 1985; Perera 2002). Revivalism, however, can also be the undoing of diversity, as postcolonial politics eventually devolved into rigidly delineated conceptions of identity. Thus, the ethos of the Pettah described by Percival has given way to mainly Sinhalese, Tamil and Muslim ethnicities (though with a handful of foreign merchants remaining - a Chinese dentist here, and a Pakistani watchmaker or Malayali gem trader there), and religious diversity has been channelled into the 
big four 'world religions' of the island: Buddhist, Hindu, Christian and Muslim. Thus, even the polis of the Pettah gradually fell subject to the forces of uniformity that characterise the modern world (Bayly 2004; Masuzawa 2005) - a process represented most succinctly by the final batch of 'Familiar Phrases' in the guidebook to Ceylon Portuguese, filled with sentences meant for encouragement 'To Speak English' (Callaway 1820, 43-4):

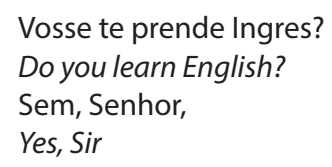

Vesse te fai muito bom, videque aquel tem hum lingo muito ne usança You do very well, for it is a language very much in fashion.

...

Ala nou tem nada que pode acha sentem travalha.

There is nothing to be had without pains

Se vos te toma travalha vos lo prende Ingres. If you take pains you will learn English

Tem basta que vos te sabe. You know enough of it already

Aquel tem basta per comça per papia.

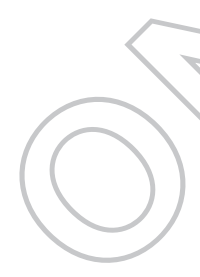

That's enough to begin to speak.

\section{Lived lives and the limits of labelling}

While the Pettah has become more uniform, diversity remains, for the strictness of identity delineations can ebb and flow with the situation at hand. Multireligious encounters are nowhere more apparent than in the Pettah, where the Sri Jayalakshmi vegetarian restaurant across the street from Dhanuka's shop displayed a photo of St. Anthony alongside its stocked pantheon of Hindu deities, draped in small coloured lights. Dhanuka also paid devotions to St. Anthony, lighting candles in the Kochchikade church bordering Pettah and port before the birth of his son (Figure 2).

Dhanuka and his wife had gotten into the habit of visiting Catholic churches during the time he spent working in Dubai, as there were no Buddhist temples around. His wife was familiar with Catholic devotional rituals from parochial school in Sri Lanka and Dhanuka found the ritual activity of lighting candles and silent prayer familiar. Religiosity in the Pettah thus presents something of a paradox. There are moments when group identities harden; Dhanuka was very proud of the fact that he was a Buddhist, and would never consider himself a hybrid anything. And when it comes to prejudice, as a young Muslim named Ashik said to me one night - his own group identity sartorially marked by skullcap and jawline beard, signalled by the Arabic calligraphy, 'Allah is all,' decorating the front of his motorcycle - 'They don't see the people! They only see the religion!' Still, 


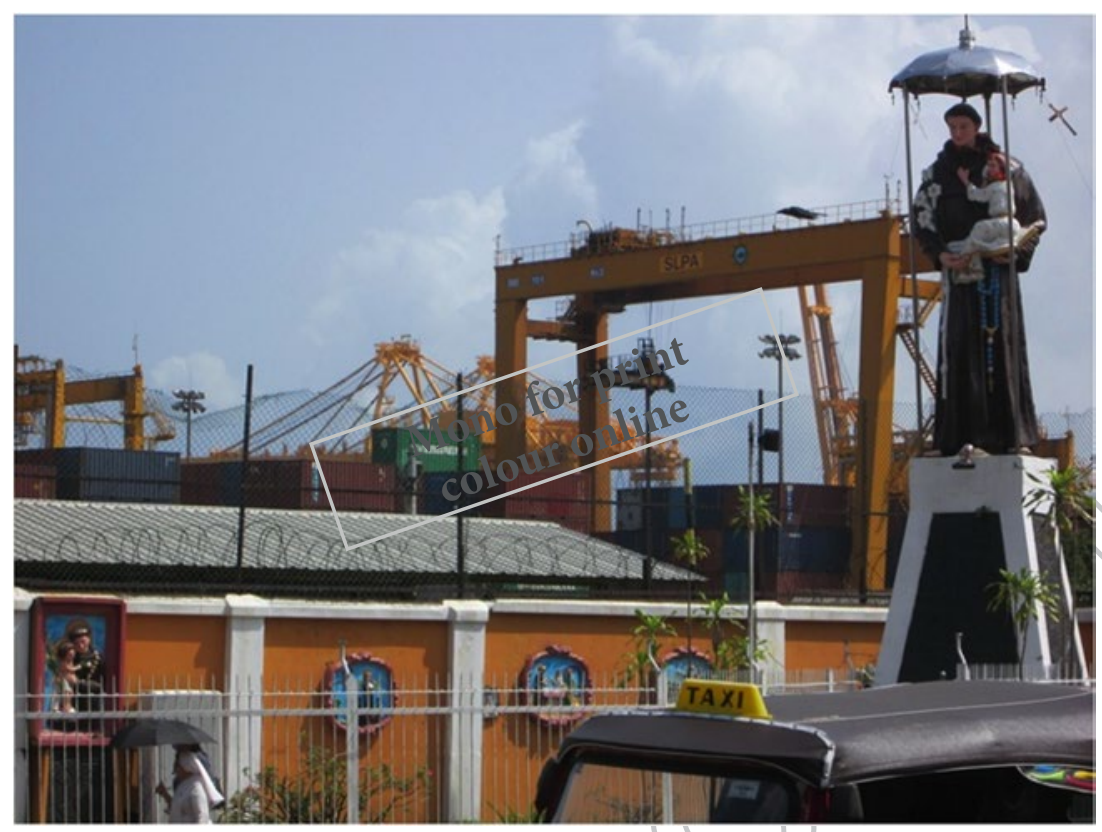

Figure 2. St. Anthony of Kochchikade. Source: Photo by author.

there are moments when these labels fade from consideration, such as when people seek a miracle from the Italian saint who hangs by the port.

Anthropologist Rohan Bastin has written on multireligious spaces in Sri Lanka, including at St. Anthony's at Kochchikade. Bastin is a scholar still invested in phenomenological concepts of sacrality and metaphysical power, whose work would no doubt frustrate the McCutcheons of the world. If, however, we understand the sacred as how a particular concept, object, space, etc. is used, then Bastin's phenomenological approach may yet have relevant purchase. Bastin highlights the Sinhala term häskam (miraculous power) to explain how the potency of shared sacred spaces draws people of all backgrounds, transgressing group boundaries and revealing a chaotic blend of tolerance and intolerance $(2012,99)$. While some of Bastin's arguments are poetic to the point of being impenetrable, he has certainly captured a reality of Lankan religious pluralism in hāskam, for the miraculous power of popular shrines is a commonly cited motivation for pilgrimage.

There are additional words that describe this. I spoke to a young trishaw driver named Jude. Since he worked in a taxi queue beside the busy traffic circle in front of the church, we could chat for only three minutes before he sped off with a hire. Jude testified to the fact that everybody (häma kenekma) comes to St. Anthony's, 'Hindus, Buddhists, some groups of Muslims (samahara muslim katțiya).'When I asked why everyone comes, he struggled to find the right word: 
'don't know ... don't know ... something ... uh ... this ... there is a blessing

(danne nä.. danne nä.. monava hari.. uh.. me.. āsírvädayak tiyenavā). The word for blessing Jude eventually landed on, āśírvādaya, is a close relative of āśvayarya, the word missionary linguist Rev. Charles Carter translated as 'miracle' or'marvel,' listing häskam as a synonym $(1924,97)$. Jude also wanted to make clear to me that St. Anthony was only a human, and that the power (balavat) really belonged to God. Yet he was impressed with the miracles of the saint; at the end of our conversation, he used the word puduma (wonder, amazement, miracle), claiming that one thousand and thirty had been performed.

When I spoke to an assistant priest at the Kochchikade shrine, he seemed at a similar loss for words initially, and the power of St. Anthony was the only reason he could give for the numbers that visited the church, evidence of a devotion he claimed was stronger than what he witnessed during a visit to St. Anthony's homeland shrine in Padua. The priest described working twelve hours per day at Kochchikade dispensing blessings, and emphasised that the location filled a market demand. It was the only church in that part of Colombo dedicated particularly to St. Anthony, and the priest explained that many Tamil Hindus have a devotion to the saint. 'Those who love St. Anthony, this is the only church they have, and so they come.' When I asked him why it was that St. Anthony was so popular among non-Catholics, he grasped for an answer. 'Because he has been uh ...... let me see ....... He has been known as the saint ........ Have you gone through the litany of St. Anthony?' The priest quickly rose and left the cubicle in the church hallway; he was gone for several minutes and a queue of devotees awaiting blessings built up. I shifted guiltily in my seat. He returned with papers that would help him better express just why St. Anthony was so respected. Flipping through the litany book he read lines aloud here and there.'St. Anthony, helper of all who invoke thee ... please have mercy on us ...

30 Liberator of captives ... Mirror of temperance ...'Thoughts finally gathered, he closed the book and launched into his own explanation:

So even among non-believers, they have very good devotion and also they have strong belief to St. Anthony, and he definitely won't send them away without help ... They will definitely be helped by St. Anthony. Ok? So that's the devotion they

have, it's the belief they have. So irrespective of their religion and caste they come here, to experience that. And also I personally have seen, a lot of people receive what they expect. What they pray for they receive from St. Anthony. So this has really been a lovely place. A lovely place.

St. Anthony is a force in the market cosmos, and the priest was unable to put it any better than that. People needed the saint and he was there. He was useful, he was sacred: hence the häskam, hence the crowds. The space thus possesses a sacred utility that defies strictly categorical language. Historian Jonathan Walters made a similar observation on public transportation, noting how'the bus in Sri Lanka is a forum' where competition between religious groups can be confrontational, yet this multireligious field is also united by a shared need for safety, 
where any deity will do so long as one moves from point A to B intact (1995, 50). Other common needs for divine intervention exist - prosperity in running a shoe shop, for example.

I find Bastin's use of the term 'chaosmos', adapted from Deleuze and Guattari $(1987,313)$, especially expressive of religiosity in the Pettah, and it can be applied well beyond his use of the term to characterise the phenomenological power of transgressing the boundaries of religious identities at shared religious sites (Bastin 2002,99). That sort of analysis still relies too heavily on boxes of bounded categories, rather than the fluidity of actions and environment. The chaos colouring the Pettah and sacrality therein comes in diverse milieu, as complex as trafficking in religious signs and symbols, and as simple as the roar of traffic itself $-\mathrm{a}$ bus as it hurtles down the cobbled street, inches from the storefronts, deafening and reeking of diesel (Figure 3 ).

The material chaos of the marketplace is mirrored by the chaotic crossing

15 of cultural strands within the cosmopolitanism of capitalism - the bricolage of words and practices assimilated from wherever the money takes you. The reason Dhanuka knew enough Hindi to entice Indian tourists towards his shoe shop was because it had been the lingua franca among South Asian workers during his time in Dubai. He owed his English, 'which I am speaking all the time broken, to his time in the Middle East as well. His speech patterns had also absorbed the Arabic turn of phrase inshallah, 'god willing', perhaps from his time in Dubai, or perhaps just from Zaruk and other Muslim friends working in the Pettah.

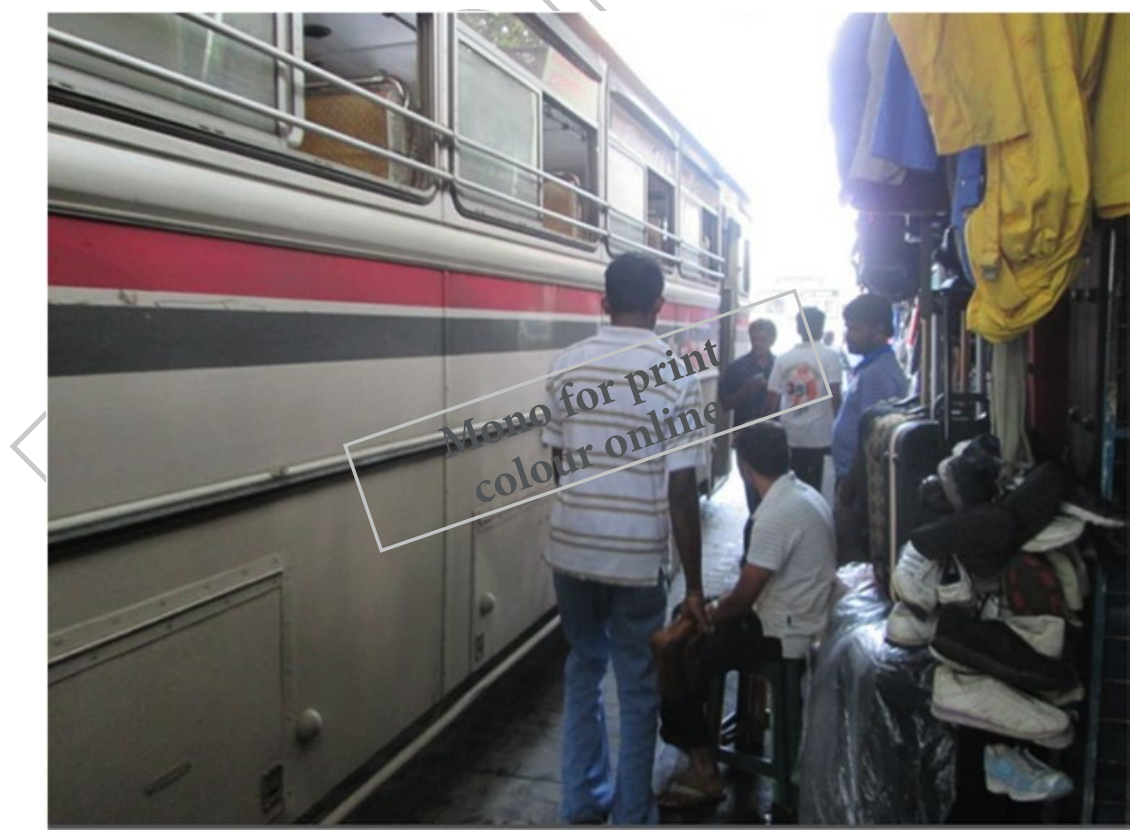

Figure 3. Bus passing shoe stalls. Source: Photo by author. 
This sort of multi-centred modern chaosmos was the bane of Eliade, a tragic tale in which worldviews previously anchored around the fixity of a single sacred had given way to the relativity of the modern world.

No true orientation is now possible ... there are only fragments of a shattered universe, an amorphous mass consisting of an infinite number of more or less neutral places in which man moves, governed and driven by the obligations of an existence incorporated into industrial society. (Eliade 1959, 23-4)

Yet from the fragments of shattered universes, new mosaics are born. Such is the case of the pluralistic Pettah, where the multiplicity of orientations that bothered Eliade are ultimately not the source of a melancholic driftlessness, but are instead responsible for the continued diverse relevancies of the sacred in everyday life. The market's instrumentalisation of sacrality is part of its driving force. In the city, time is a commodity like any other, and sometimes it is used sacredly. Time, in turn, provides more precise language for describing the lived religiosity of the Pettah. Labels fluctuate, but we always reside temporally.

\section{Starts, stops, seconds - momentary religiousness}

When Dhanuka got to the market around ten o'clock he had a routine. Unlocking the sheet-metal door to his shop, he threw it upward. He removed the wire racks which are attached to the side of his doorway and hold more shoes for display. These model shoes, with a small nail hammered into the heels for hanging purposes, were removed from a box and flicked one by one with a feather duster before being hung. Dhanuka, next took out his broom and removed the inevitable accumulation of overnight grit from his shop floor before sprinkling water outside the door. I thought this last manoeuver might have some sort of religious significance to it, but Dhanuka explained it was practical, simply because 'so many dust is coming inside.' He tossed out his rubber welcome mats onto the brick street and then began to attend to his religious obligations.

I never saw a shop in the Pettah that did not have a religious shrine inside it, though these came in all shapes and sizes with various levels of attendance. The owner of the bootleg DVD stall on the other side of Sunil's shop, for example, had a Buddha blackened with grit, to which I rarely saw him attend ritually. Dhanuka, on the other hand, was more careful with his sacred space - a modest corner at the end of a shoe shelf. His white Buddha statue was wrapped in protective plastic, with a bottle of oil beside it for lighting lamps. Behind the statue hung another bottle, one of the four at each corner of his shop. These were to protect against the'eye poison' of jealous market competitors - a practice he replicated in his home (Figure 4).

40 Dhanuka's most persistent ritual was incensing and praying. He was certain to perform this each morning, and then would repeat it periodically throughout the day whenever business would slow. It was one of a number of habits that he and his friends had for fighting boredom on slow days. They would run across 


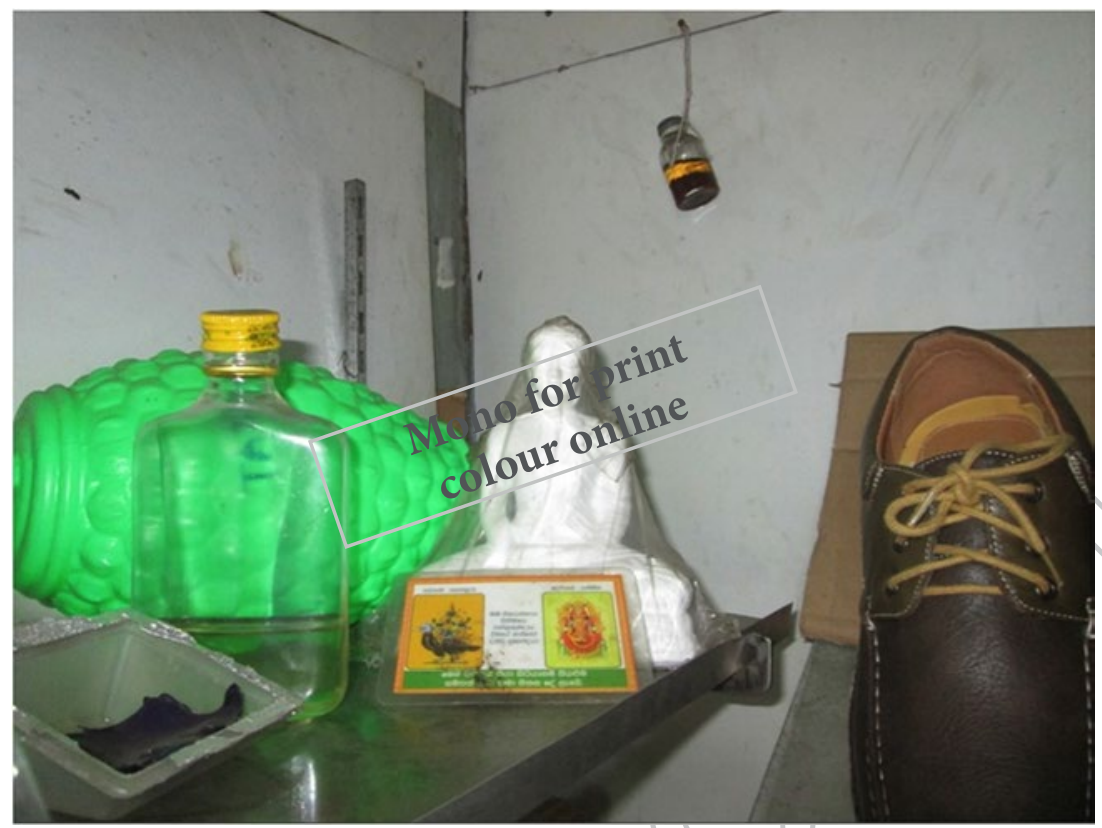

Figure 4. Dhanuka's shrine space. Source: Photo by author.

the street to Sri Jayalakshmi restaurant to get cups of tea for one another, or buy a cigarette from the corner store and pass it back and forth. Whether Dhanuka would light another stick of incense seemed to have a similar impetus - a matter of being at loose ends for a few moments. Though I was the anthropologist, he was the one who questioned me when he noticed me watching him wave the stick of incense.

'You know why l'm doing this?' he asked. I had a good idea, but I played dumb.

'To make the shoes smell better?' I offered.

Dhanuka laughed and said yes before elaborating. 'Sometimes when we are having a bad day and too little customers are coming, we do this and pray to god. You know pray?' He pressed his hands together. I began to attempt an explanation about my knowledge of prayer, but he interrupted. 'Like this?' He quickly recited a prayer in Sinhala directed towards the Buddha having to do with keeping good health. It was swift and automatic. 'There are different prayers for different things,' he explained.

We are trusting, we are keeping this thing and praying our Lord Buddha: 'Give me something.' Like that we are thinking: 'Good business.' If we don't have business we are making this thing, going like this, please help me, like that. Because I am not a rich guy. I am very poor. Not too poor. I am middle class in my country.

In moments of boredom Dhanuka sometimes decided to make the next few seconds sacred - ritual moments that did not arrive at prescribed times, but 
rather found whatever spaces they could in the constant pressing forward of time in the Pettah. Often these moments were sparked by the anxiety of slow sales; making ends meet was a constant concern of Dhanuka's, and performing his incensing and prayer rituals eased his mind, placing trust in Lord Buddha's help. Of course, the demands of the market also meant that Dhanuka's ritual was frequently interrupted, which incidentally happened on the day I had asked him to record the prayers with my audio recorder. Listening now to the preserved sounds, I hear the regular interruption of passing traffic, which drowns out Dhanuka in brief passing bursts. When his voice drops a few decibels on the recording I know a customer has walked into the shop. Dhanuka did not stop his prayer right away, and the customer did not directly interrupt him, but gandered instead at the shelves. Dhanuka wrapped things up quickly, however, not wanting to lose business, and stuck the incense in a shelf near the doorway before switching to the ritual of selling shoes, which comes with a formula just as automatic as his prayers. In the end, the customer left without buying anything. 'Choosy guy,' Dhanuka said disdainfully. 'Actually, that guy doesn't even want to buy shoes. Fucking guy.' Dhanuka stalked over to Sunil's to lighten his mood by cracking a joke with Zaruk. The stick of incense continued to burn over the shoes, gradually becoming ash, replaced afresh whenever Dhanuka next thought to (Figure 5).

20 The marketplace is a space where the sacred stands beside the often quite literally profane. Profanity and sacrality can both be understood as techniques

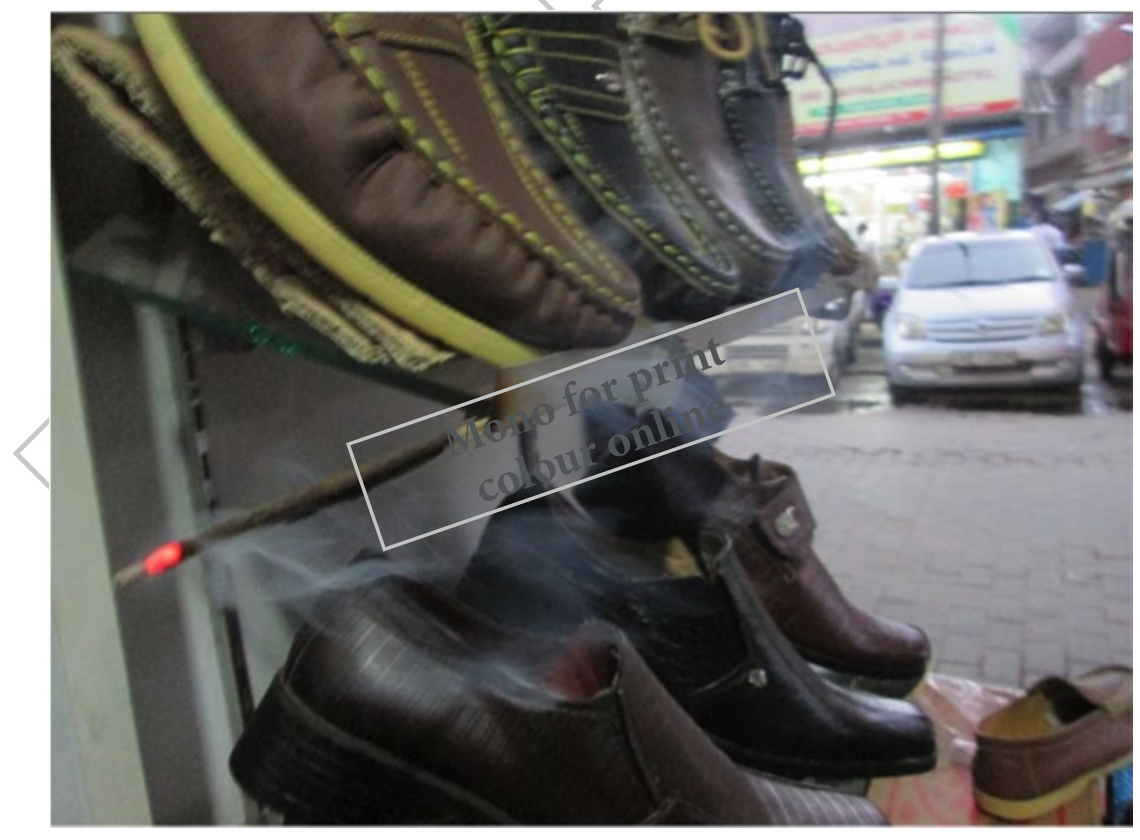

Figure 5. Incense burning over shoes. Source: Photo by author. 
for meeting the demands of Pettah business. In Dhanuka's case, incensing eased economic anxieties while cursing vented the frustrations of failed sales. In this way, the data from the marketplace help unravel Durkheim's confusion on where these concepts begin and end. While he remarks early in Elementary Forms of Religious Life that the distinction between the sacred and the profane is absolute, he later tempers this assertion by noting how:

By a sort of contradiction, the sacred world is as though inclined by its very nature to spread into the same profane world that it otherwise excludes. While repelling the profane world, the sacred world tends at the same time to flow into the profane world whenever that latter world comes near it. $(1995,322)$

If, however, one understands the sacred as a measure of something's use, then there is no contradiction in the fact that it can function with a dual action, capable of both merging with and repelling the profane world. Dhanuka used the sacrality of anti-sorcery devices to repel the jealous intentions of others, and he also habitually prayed to Lord Buddha with the particular intention of material success, thus interweaving religious ritual with the material desires of his life. Mikhail Bakhtin eloquently expressed similar patterns in a mediaeval European context, noting 'that special marketplace atmosphere, in which the exalted and the lowly, the sacred and the profane are leyeled and drawn into the same dance' $(1984,160)$.

Moreover, material success in life is often expressed through religious idioms. There seemed to be a correlation between the relative success of a business and the elaborateness of its shrine. Upgrading these micro sacred spaces is part and parcel of an overall reinvestment in one's business, expanding to attract customers. Thus, religious performance is another form of wealth performance. Sunil took me one day to his brother's shop for an introduction. The Nanayakkara family had more than a foot in the Colombo shoe business, owning many stores in several neighbourhoods. Sunil's brother's was certainly the swankiest of the shoe stalls along this block of the Pettah, able to afford a glass front window and door and air-conditioning. In the ceiling a small rotating light spun its colours over the impressively diverse selection of shoes. Sunil's brother sat upright at his desk, his two younger attendants (the equivalents of Sunil's Patrick and Zaruk) shifted their weight listlessly waiting for customers. It seemed the glass storefront also served the function of penning them in and preventing the sort of wandering joking that happened with Sunil's assistants. The brother looked much like Sunil, though his moustache was more trim and his hair shorter and straighter. He was engaged in his morning religious preparations, pouring oil into his small lamp before lighting it and placing it in front of the Buddha image on hanging on the wall. The only image of a deity was an ostentatiously large picture of Lakshmi on the adjoining wall, the goddess of wealth being a notable display of the man's success. He practised an interrupted sort of ritual, asking me questions periodically, and then pausing conversation so as to soundlessly move his lips in recitation of prayers to match the particular steps of this ritual. 
Some of the seconds in this encounter were more sacred than others; it was a religiosity that came in stops and starts.

Back at his own shop Sunil showed me a well-read book. The cover had been re-taped at the spine and nearly all its writing was worn away, though one could still faintly make out what was perhaps the title $-\square \square \square \square$, Nivana. Sunil blamed its condition on the fact that so many of his friends had borrowed it over the years. It was a book of Buddhist philosophy translated into laymen's conversational Sinhala. I browsed the chapter titles, noticing especially 'Why is it important to meditate?' and 'Do you love yourself?' I asked Sunil if he read the book regularly and he said yes, whenever there was some downtime in the shop. I asked him if he meditated, but he scrunched his face and lamented the fact that he did not. There wasn't enough time, and whenever he tried his mind would just go running all over the place. Any meditation instructor will tell you this is a natural part of the meditation process that must be worked through gradually, but I guess for Sunil it was quiescence or bust. Sunil devoted so much of his time and thought to the shoe business, he rarely had a moment to sit still. Constantly taking business calls, Sunil never knew when his next free minute would arrive. His sort of time did not have the stability needed for dedicated meditation practice, but he was able to find a second or two here and there to slip in a bit of nivana in book form and share it with others. Enlightenment, interrupted.

\section{Switching it on - performing sacrality and identity}

Sacred seconds can be put to use for mental or material needs. This section focuses especially on the latter and the way religious performance can be deployed for this end. In general, the public display of religious identity by a wide swath of the Lankan working class - shop owners, trishaw drivers, bus operators - has accelerated in postcolonial modernity (Obeyesekere 1972; Walters 1995). For this reason, many scholars have focused on how sites of multireligious encounter are fraught with a tension between cooperation and competition (Obeyesekere 1978; Walters 1995; Bastin 2002; De Silva 2013). Such political

30 implications certainly cannot be ignored in the Pettah - an epicentre of the country's most remembered instance of anti-Tamil communal rioting, 1983s Black July. Yet when it comes to the sacred second, the political implications are usually subtler than the more permanent displays of slogans on buses, invoking the blessings of the gods, Buddha, Jesus, or Allah. The identity politics of the sacred second are most often coded in the politics of the marketplace, which almost always concern the bottom line. Performance is linked to sales.

Patrick was Sunil's most talented salesman, an ability that was in part linguistic, being able to speak Sinhala, Tamil, and English. Patrick was another example of the uniquely transnational cosmopolitanism of the Pettah. He had spent a formative ten years of his life, from eight to eighteen, living in Australia, during 
which time he confessed he had not been a diligent student, preferring instead to 'be a gangsta' with the mixed crowd of kids at his school who were uniformly dubbed 'blackies' by the white student body. This unique educational trajectory meant his language skills were primarily verbal, and he was marginally literate only in English. He spoke somewhat disparagingly about the vanity of those who seek jobs in the Colombo Fort, pointing out a couple guys in dress shirts and pants, wearing their matching pointed leather office shoes, saying they looked like big men, but in reality probably made less per month than he did. Patrick has held a variety of odd jobs throughout his 20 s. After a brief stint in an underworld brute squad that an ex-girlfriend dissuaded him from continuing, he worked as a hotel nightclub manager, at his own food stall in the cafeteria of the Colombo United Nations building, in his own electronics shop, then at Sunil's, and now as manager of another shoe stall down the block. Although his friends and family encouraged him to put his language skills to use at a more lucrative profession, Patrick seemed content. He was discouraged by the failure of his past two entrepreneurial endeavours as a shop owner, and he preferred the laidback atmosphere of the marketplace to the competitive hotel or office work industries. It was also clear he enjoyed the art of haggling and staying ahead of market trends -

It's kind of like a big game. If you go home at night and sit and think about all that goes into what we do everyday, there's actually a huge story behind it, but in the moment it just sort of happens. Natural.

This natural sort of salesmanship flowed out of Patrick whenever a customer stepped into the shop. The main sales strategy of Pettah shopkeepers seemed to be to get the customer to linger before the product as long as possible. The longer they stood there, the greater the chance they would become attached to what they were holding (a good salesman always made them handle the product) and decide to buy it. Thus, it was up to the shopkeeper to continue to improvise facts about the product and keep the customer listening, to fluff egos and vanity, encouraging the customer to have a seat and to try a pair on. This was all meant to build up to the critical question, of 'how much?' - the signal that the price haggling was set to start, which constituted its own sort of mind-reading dance of feigned indifference between buyer and seller. Patrick had a knack for casually luring customers through this type of conversation, quickly rattling off a number of reasons why the shoe they were examining was perfect for them: the top of the shoe won't crease as you walk around the office, Patrick explained bending the toe back, and the buckle on this loafer matches your belt, this one has that'rich look', and the line in the toe of this shoe is meant to match the pleat in your dress pants, while the heel on this one is custom designed for comfort, 40 durability, and lightness. The reasons fell one after another - a verbal barrage as the customer stood with the shoe in his hands, trying to gauge the extent to which he was willing to be scammed. If the sale prospects took a turn for the worse, Patrick also possessed a particular talent for off-the-cuff rationalisations 
about defects in the shoes, occasionally throwing me a wink after delivering one of these. Once when he was about to lose a customer for not having a big enough size in stock, I witnessed him make the sale anyway by taking out the entire insole, explaining that the interior padding was not really necessary. Wink.

If necessary, Patrick's sales performance could turn seconds sacred, as he continued winking all the way to the bank. One early morning in Sunil's shop, Patrick was still organising stock when an elderly couple walked in. Zaruk had yet to arrive and Sunil was across the street buying tea, so Patrick sprang to his sales duties, pulling down a number of sandal models the gentleman was eyeing. My own mind was groggy at the early hour and I began to tune out the familiar sales rapport, eyes set on the Sri Jayalakshmi restaurant as I pondered going to fetch some tea for myself. When I glanced back at Patrick, however, my attention snapped back to the scene at hand as he was doing something I had never seen before. He had made the sale, and I watched him kiss the bill and then gesture with the money upward towards the shrine in Sunil's shop, situated beside the ladder leading into the small attic where the extra wares were stored (Figure 6).

After he bagged the sandals and the couple left the shop, Y asked him what that was all about. He grinned. 'Did you see what I did there?' I told him I had never seen him kiss money and offer it before. 'It was a sort of trick,' he explained.

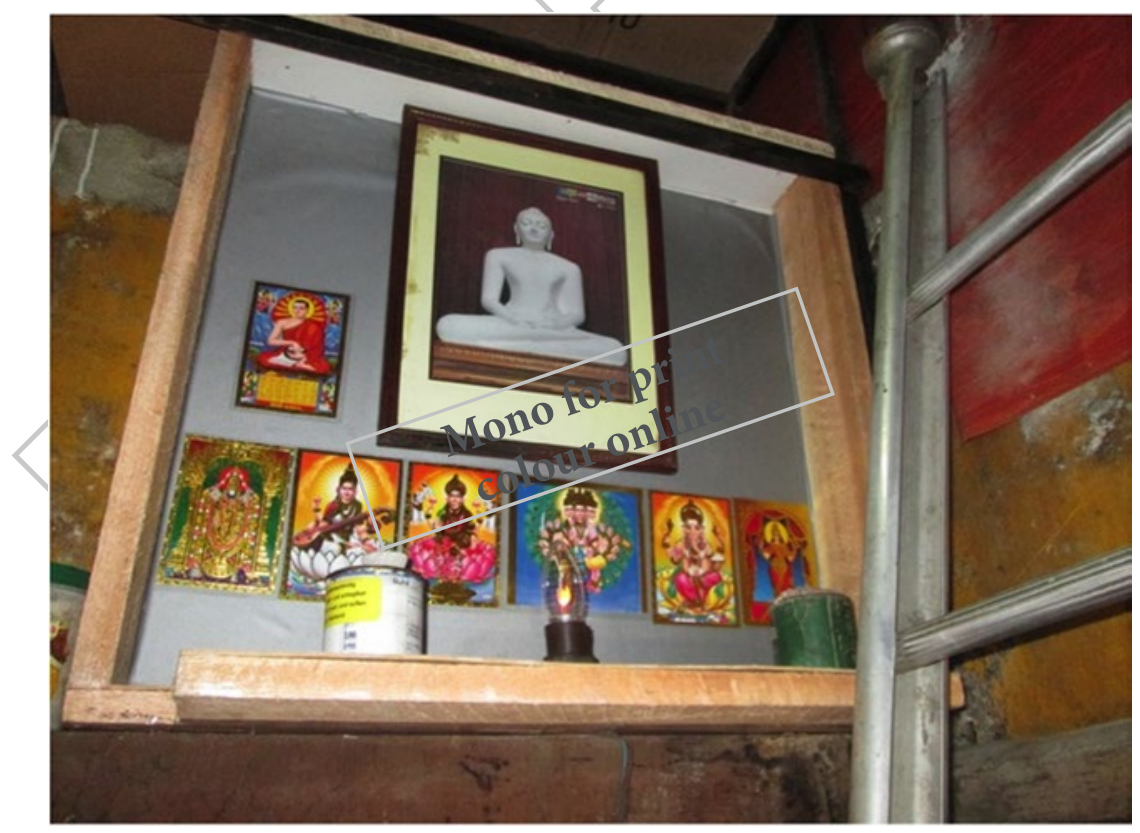

Figure 6. Sunil's shrine space. Source: Photo by author. 
I told them they had come to the shop so early that I had not even had time to light the shrine lamp or incense yet for Lord Buddha. A lot of Sinhalese like that if you show respect to their religion, but they don't know I'm a Hindu.

Thus Patrick made an ad hoc calculation that the couple to which he was selling were likely pious and that they would respond positively if they sensed he was, too. By making those seconds sacred, Patrick had helped to make some money. The most intriguing part of this explanation of his religious performance, however, is that Patrick was not actually a Hindu in the devotional sense of the term. Although he identified as half Tamil (an ethnicity often linked to Hinduism) from his estranged father's side of the family, religiously Patrick had been Catholic all his life. In fact, this event at Sunil's happened shortly after the two of us had returned from a weeklong pilgrimage to the shrine of St. Anne in Thalawila. In this moment of explanation, however, 'Hindu' had stood in for'not Sinhalese,' Patrick's point being that he had used a bit of religious posturing to grease the wheels of commerce with a Buddhist. ${ }^{2}$

Only adding to the complexity of this identity performance, I once witnessed Patrick adopt a specifically Sinhala label as well. This came on our pilgrimage, when the van had set out and his cousins opened our journey by reciting a decade of Hail Marys. Thinking I had not understood the Sinhala version of this prayer, Patrick wanted to tell me that this was in fact the Hail Mary, but the English name of the prayer suddenly escaped him. As he drew a blank his young cousins giggled, teasing him that of all people, the guy who had lived in Australia should be able to come up with the answer. Patrick retorted quickly in Sinhala:'I live in Sri Lanka, no? So now I'm Sinhala.' At the moment, I had thought this response a poetic modern example of a phenomenon that historians of Sri Lanka have long discussed - the way in which Sinhala identity has acted

30 as an assimilative cultural force throughout the long arc of the island's history, gradually folding migrant groups and religious concepts into the mechanisms of the local caste system and pantheon (Roberts 1980, 1982; Obeyesekere 1984; Holt 2004). This event in the market several days later, however, demonstrated that Patrick's self-labelling retained a great deal of fluidity, and that he was able to manipulate its performance to fit the situation at hand, whether deflecting teasing or presenting himself as an expert salesman in the way he instrumentalised a few seconds of his market time as sacred so as to sell to Buddhists.

After Patrick had explained his sacralized sales tactic to me, another customer approached the shop. 'Watch,' he said throwing me a wink, 'I'll do it again.'This 40 time I paid closer attention to the conversation, and sure enough Patrick complemented this young man on getting his shopping done early in the morning, so early in fact that Patrick had not yet lit the shrine lamps. The man seemed impressed by Patrick's piety and not only bought a pair of shoes, but offered his own blessing as a customer towards the future prosperity of the shop. Again Patrick performed this market religiosity by kissing the money and offering it towards the shrine. As the man left with his shoes, Sunil returned from across 
the street. Patrick proudly told him how he made the last two sales, and especially about the small blessing he had received. Sunil smiled and nodded, both slightly, handing Patrick the glass of tea he had brought for him. \\ The shops under the bo tree - conclusions}

The Pettah is a complex cosmos. In the space of two shoe stalls we find Buddhist, Hindu, Muslim, Catholic, Tamil, and Sinhala labels at play, mixed with imports from travel abroad, cultural streams from Australia and Dubai. The Pettah is a space of strategy and play, cunning and humour, rivalries and solidarity. Over the course of a ten-hour day in the market, 36,000 s pass by. No more than a few thousand of these would ever be counted as sacred, and they certainly do not come all at once in uninterrupted fashion. I am not attempting to formally quantify or measure these seconds. They are more a function of perspective and a source of metaphor - the pace of a slowly resting heartbeat, yet ceaselessly pressing forward; a unit of time emblematic of modernity. Among these beats sacrality fits in where it can and is called upon when needed; it conforms to the marketplace.

The shoe shops in this paper sat beneath a large bodhi tree (ficus religiosa), the same sort found in every temple complex, under which the Buddha was said to gain enlightenment. Perhaps/was subconsciously drawn to these shops for this reason when I set out to study religion in the Pettah. The tree certainly stands out, one of only two on the block. Or perhaps I was drawn because it offered a bit of shade. The coolness it provided to his shop was what Dhanuka thought of when I mentioned the tree to him. I kept bringing it up to people in passing, trying to draw out a spontaneous religious observation about the

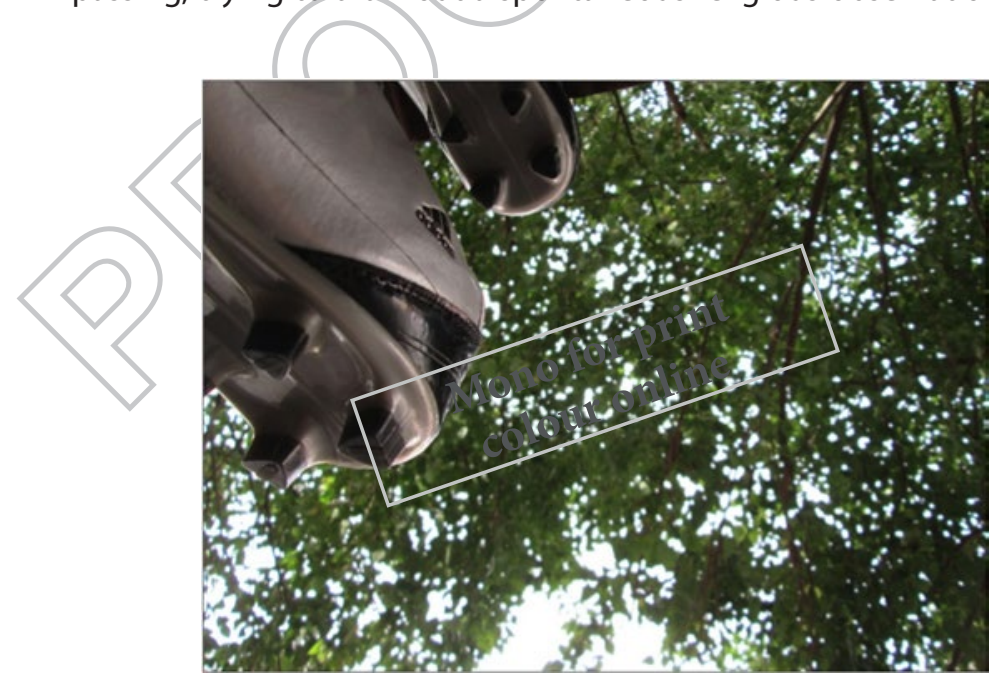

Figure 7. Shoes beneath bodhi tree. Source: Photo by author. 
tree without asking a leading question. Usually, however, I received responses similar to Dhanuka's - some practical observation, either about its shade, or the nuisance of its seed pods dropping, or its providing shelter from rain (Figure 7).

I had actually given up on using the tree to frame my project at all. If others did not recognise the religious significance of it in the market context, then I was not going to force it. Then one night Patrick came up behind me as I was looking up at the street lamp in front of Sri Jayalakshmi across the road. Its orange sodium vapor glow was beaming down on us.

'Sunil says the fact that there is a break in the branches here so that the light can reach our shop at night is a blessing,' Patrick said motioning up towards the tree.

'Yeah? I thought it was poetic that your shop was under a bodhi tree.'

This was apparently an adjective with which Patrick was unfamiliar. 'What? You mean like, it's a sin?'

'No, No. It's a good thing. Like, it's fitting. An auspicious thing.'

'Ah,' Patrick turned to Sunil and relayed to him in Sinhala the fact that I thought it was auspicious for his shop to be beneath a bodhi tree. Sunil smiled and nodded, remarking that it was a blessing and this meant one needed to be mindful of conduct in such a space.

This incident with the bodhi tree emphasises the central point I have been making about sacred time in the market. For most of the day, the shopkeepers pass beneath the tree without giving it a second thought, beyond perhaps being thankful for a respite from the sun. The tree does not factor into their usual calculations, and they may even speak ill if it nuisances them. But when the seconds become sacred and the mind turns to blessings, the religious significance of the tree comes to the fore. The fact that Patrick assumed / thought conducting market business under a bodhi tree was a sin demonstrates his awareness that a great deal of profane activity went on in the market and that it contrasted with the sacrality of this religious sign. Sunil was aware of this as well, no stranger to the techniques of salesmanship, and mentioned the inappropriateness of fibbing beneath such foliage. Yet the tree was still a blessing for him, a reminder of Buddhist teachings and an inspiration to lead an upright life. That is, when he thought of it. Until the next second passed.

\section{Notes}

1. Hamsa Sandeśa, v.79. My translation from Paññāsāra's edition (2011). Jayasuriya's translation also consulted (2005).

2. My own interpretation, of course. I did not ask Patrick to explain what he meant by Hindu any further. I did, however, read his own quote back to him after I wrote it down, and he assented that I had gotten it right, offering no additional comment.

\section{Acknowledgements}

Thanks to professors Leela Prasad and David Morgan for feedback on drafts of this article. 


\section{Disclosure statement}

No potential conflict of interest was reported by the author.

\section{References}

1849. Ceylon. Papers Relative to the Affairs of Ceylon, Presented to Both Houses of Parliament by Command of Her Majesty. London: W. Clowes and Sons.

1893. The Use of Opium and Bhang Spreading in Ceylon, Especially in Colombo: And the Need for Specially Restricting the Sale. Edited by Ceylon Observer. Colombo: Ceylon Observer Office.

2005. Hamsa Sandeśa. Translated by Edmund Jayasuriya, Classical Sinhalese Texts Translation Series No. 3. Panaluwa: Central Cultural Fund.

Bakhtin, M. M. 1984. Rabelais and His World. Translated by Helene Iswolsky. 1st Midland book ed. Bloomington: Indiana University Press. Original edition, 1965.

Bastin, Rohan. 2002. The Domain of Constant Excess: Plural Worship at the Munnesvaram Temples in Sri Lanka. New York: Berghahn Books.

Bastin, Rohan. 2012. "Saints, Sites, and Religious Accommodation in Sri Lanka." In Sharing the Sacra: The Politics and Pragmatics of Intercommunal Relations around Holy Places, edited by Glenn Bowman. New York: Berghahn Books.

Battúta, Ibn. 1929. Travels in Asia and Africa: 1325-1354. Translated by H. A. R. Gibb. London: George Routledge \& Sons.

Bayly, C. A. 2004. The Birth of the Modern World, 1780-1914: Global Connections and Comparisons, The Blackwell history of the world. Malden, MA: Blackwell.

Biedermann, Zoltán. 2014. The Portuguese in SriLanka and South India: Studies in the history of diplomacy, empire and trade, 1500-1650, Maritime Asia. Wiesbaden: HarrassowitzVerlag.

Boyer, Pascal. 2001. Religion Explained: The Evolutionary Origins of Religious Thought. New York: Basic Books.

Callaway, John. 1820. A Vocabulary, in the Ceylon Portuguese, and English languages, with a series of Familiar Phrases. Colombo: Wesleyan Missionary Press.

Carter, Rev. Charles. 1924. A Sinhalese-English Dictionary. Colombo:The "Ceylon Observer" Printing Works.

Castellani, Aldo, and Marshall Philip. 1914. "Plague in Ceylon." The British Medical Journal 1 (2779):752-753. doi:http://dx.doi.org/10.2307/25309436.

Deleuze, Gilles, and Felix Guattari. 1987. A Thousand Pleateaus: Capitalism and Schizophrenia. Translated by Brian Massumi. Minneapolis: University of Minnesota Press. Original edition, 1980.

De Silva, Premakumara. 2013. “Reordering of Postcolonial Sri Pada Temple in Sri Lanka: Buddhism, State and Nationalism." History and Sociology of South Asia 7 (2): 155-176.

Dharmasena, K. 1985. "The Port and Dock Workers of Colombo 1860-1960." The Great Circle 7 (2): 100-115. doi:http://dx.doi.org/10.2307/41562519.

Durkheim, Emile. 1995. The Elementary Forms of Religious Life. Translated by Karen E. Fields. New York: Free Press. Original edition, 1912.

Eliade, Mircea. 1959. The Sacred and The Profane; The Nature of Religion. Translated by Willard R. Trask. 1st American ed. New York: Harcourt.

Gibson, Ashley. 1922. "A Rose-Red City." Fortnightly review 111 (664): 690-701.

Gooneratne, Yasmine. 1966. "The Two Societies: A Study of Town Life in Nineteenth-Century Ceylon." The Historical Journal 9 (3): 338-359. doi:http://dx.doi.org/10.2307/2637985.

Grimes, Ronald L. 2006. Rite out of Place. New York: Oxford University Press. 
Holt, John Clifford. 2004. The Buddhist Vișnu: Religious Transformation, Politics, and Culture. New York: Columbia University Press.

Latour, Bruno. 1993. We Have Never Been Modern. Translated by Catherine Porter. Cambridge: Harvard University Press.

Masuzawa, Tomoko. 2005. The Invention of World Religions. Chicago, IL: University of Chicago Press.

McCutcheon, Russell T. 2001. Critics Not Caretakers: Redescribing the Public Study of Religion. Albany: SUNY Press.

Muller, Carl. 1995. Colombo: A Novel. New Delhi: Penguin Books.

Obeyesekere, Gananath. 1972. "Religious Symbolism and Political Change in Ceylon." In The Two Wheels of Dhamma: Essays on the Theravada Tradition in India and Ceylon, edited by Gananath Obeyesekere, Frank Reynolds and Bardwell L. Smith, 58-78. Chambersburg, PA: American Academy of Religion.

Obeyesekere, Gananath. 1978. "The Fire-Walkers of Kataragama: The Rise of Bhakti in Buddhist Sri Lanka." The Journal of Asian Studies 37 (3): 457-476.

Obeyesekere, Gananath. 1984. The Cult of the Goddess Pattini. Chicago, IL: University of Chicago Press.

Paññāsāra, Okkampițiyē, ed. 2011. Haṃsa Sandēśaya: Anvaya, Padagatārtha, Viyataṇa hā Vivaraṇa. Nugēgoḍa: Kartru Prakāśanayaki.

Percival, Robert. 1805. An Account of the Island of Ceylon Containing Its History, Geography, Natural History, with the Manners and Customs of its Various Inhabitants: To Which is Added, the Journal of an Embassy to the Court of Candy: Illustrated by a Map and Charts. 2nd ed. London: C. and R. Baldwin.

Perera, Nihal. 1998. Society in Space: Colonialism, Nationalism and Post-Colonial Identity. WestviewPress.

Perera, Nihal. 2002. "Indigenising the Colonial City: Late 19th-century Colombo and its Landscape." Urban Studies 39 (9): 1703-1721.

Philip, W. M., and L. F. Hirst. 1917. "A Report on the Outbreak of the Plague in Colombo. 1914-1916."Journal of Hygiene 15 (4): 527-564. doi:http://dx.doi.org/10.2307/3859064.

Roberts, Michael. 1980. “From Southern India to Lanka:The traffic in Commodities, Bodies and Myths from the Thirteenth Century Onwards." South Asia: Journal of South Asian Studies 3 (1): $36-47$.

Roberts, Michael. 1982. Caste Conflict and Elite Formation. New York: Cambridge University Press.

40 Roberts, Michael. 1985. “I SHALL HAVE YOU SLIPPERED': The General and the Particular in an Historical Conjuncture." Social Analysis: The International Journal of Social and Cultural Practice 17: 17-48. doi:http://dx.doi.org/10.2307/23171792.

Rockhill, W. W. 1915. "Notes On the Relations and Trade of China With the Eastern Archipelago and the Coast of the Indian Ocean During the Fourteenth Century." T'oung Pao 16 (1): 374-392.

Strathern, Alan. 2007. Kingship and Conversion in Sixteenth-Century Sri Lanka: Portuguese Imperialism in a Buddhist Land. Cambridge: Cambridge University Press.

da Trinidade, Paulo. 1972. Chapters on the Introduction of Christianity to Ceylon: Taken from the Conquista Spiritual do Oriente. Translated by Edmund Peiris and Achilles Meersman. Colombo: Colombo Catholic Press.

Walters, Jonathan S. 1995. "Multireligion on the Bus: Beyond 'Influence' and 'Syncretism' in the Study of Religious Meetings." In Unmaking the Nation: The Politics of Identity and History in Modern Sri Lanka, edited by Pradeep Jeganathan and Qadri Ismail. Colombo: Social Scientists' Association. 